\title{
DETERMINATION OF SAFE GRADE ELEVATION BY USING HEC- RAS: CASE STUDY MUTHA RIVER
}

\author{
Ritica Thakur ${ }^{1}$, Deepali. R. Vaidya ${ }^{2}$ \\ ${ }^{1}$ M.E Second Year Hydraulics student, Department of Civil Engineering, Sinhgad College of Engineering, Pune \\ University, SCOE Vadgaon (BK), Pune, Maharashtra, India. \\ ritica.thakur@gmail.com \\ ${ }^{2}$ Asst. Professor, Department of Civil Engineering, Sinhgad College of Engineering, Pune University, SCOE Vadgaon \\ (BK), Pune, Maharashtra, India. \\ drvaidya.scoe@sinhgad.edu
}

\begin{abstract}
Flood is a naturally occurring disastrous event causing damages, losses and destruction to property, life and environment. Hundred millions of money are spent every year in flood control and flood forecasting. For construction of any structure near by a water body or in between a water body and for determination of safe levels of construction to protect structure from flood water, safe grade elevation is required.

In order to evaluate or estimate, mitigate and handle the floods, the present paper presents a methodology for assessment of flood line to produce safe grade elevation by using River Analysis System made by Hydrologic Engineering Center (HEC-RAS) software which is predominately used in the field of hydraulic analysis for floodplain delineation. The general parameter affecting flood is runoff gauge, discharge, rainfall and land use as spatial data. This paper explains the use of the HEC-RAS for producing the safe grade elevation for Mutha River from its origin at downstream side of Kadakwasla dam till Mahtre Bridge. It explains the methodology to construct a table model and how to validate it. The methodology developed can be applied for regions if only predominant factors affecting the flood in that region is consider, to decide the best economical safe grade elevation for the building or structure near or on the river and would help in planning priorities prerequisites for managing flood efficiently.
\end{abstract}

Keywords: Safe Grade elevation, Parameters, Mutha River, Flood, spatial data, Zoning.

\section{INTRODUCTION}

A flood is a condition of unusually rise in stage of a river, it is the level at which the banks of river overflows and the adjoining area inundates. India is enlisted as most floodaffected countries of the world.

Floods cause severe bank erosion if the river banks are fragile and not protected against the heavy flood discharges. Loss of life, economic loss and loss of property are all results caused by floods. There are two options for flood management viz. structural measures \& non-structural measures. The modern flood management strategy is a judicious mixture of both options. For this hundreds of millions of money are spent every year in flood control and flood forecasting. Flood proofing of important structures is also accomplished by combination of adjustment and / or addition of features to buildings that eliminate or reduce the potential for flood damage. One of them is by providing safe elevation to the building. For the construction of any structure near by a water body or in between a water body, determination of safe levels of construction is find out to protect the structure from flood water. This elevation is called as safe grade elevation. Safe grade elevation is the elevation given to the building as a height or plinth height to stop the intrusion of water into the building.
This measure is used for the construction of important power projects, buildings and other structures. The guideline of National Disaster Management Authority, Government of India also recommends that the installations of national importance structure i.e. important structures with respect to life of people or money should always be above the specified flood level for example Nuclear power plant, Bridges, industries or any residential projects, etc. For the safety of the structure it is recommends that in addition to the flood caused by precipitation, other possible flood sources are to be evaluated for estimation of maximum flood level.

Safe grade elevation is calculated by knowing the maximum stage of the river in previous years and the worst probable stage the river may have. This can be achieved by computing the surface profile computation of the river for different discharged condition of the river. We are using HEC-RAS software for generation of the one dimensional surface profile model of the surface of the Mutha River.

US Army Corps of Engineers (1982) Hydrologic Engineering Centre developed HEC-RAS, which is based on standard step method. It is being widely used in many countries for water surface profile computations and proved to be very accurate and useful. 
HEC-RAS is a program which performs water surface profiling in one dimension. To generate model in HEC-RAS requires definition and descriptions of the land surface and hydrologic events flow data. The flow data and geometric data are used to calculate gradually, steady, varied flow water surface profiles (steady-flow module) from energy loss computations. HEC-RAS is capable of performing a modelling a full network of a dendrites system, channels, or a single reach.

\section{LITERATURE REVIEW}

In a paper presented by Guan Tie-sheng. This paper discusses the flood safety of the Banqiao and estimation of inflow flood designed parameters. After performing flood routing, they concluded that $117.76 \mathrm{~m}$ of water level and $2000 \mathrm{~m}^{3} / \mathrm{s}$ of maximum discharge as 100-year floods parameter; $118.92 \mathrm{~m}$ of water level and $13500 \mathrm{~m}^{3} / \mathrm{s}$ maximum discharge as 5000- year flood parameter, and $119.63 \mathrm{~m}$ of water level and $14400 \mathrm{~m}^{3} / \mathrm{s}$ of maximum discharge as 10000-year flood parameter .

$A$ report drafted by CWPRS which discuss one and two dimensional model studies for prediction of changes in flow conditions in Panvel creek due to development of proposed International Airport at Navi Mumbai, Maharashtra. CWPRS, Pune, conducted a one dimensional model study by using Charima. A two dimensional plot was prepared by using MIKE 21, showing the difference in maximum velocity between with and without airport cases. The tidal water levels predicted from the Charima model and the MIKE 21 model are in close agreement.

A report was drafted for estimating the designed flood and safe grade elevation for nuclear power project at Gorakhpur, Haryana. In this Report, the hydrological analysis had been performed on basin boundary and was extended to districts of Jind, Kaithal and Hissar to study the safe grade elevation for the nuclear power plant. MIKE 11 software was used for one dimensional modelling of dam break analysis of Bhakra Dam. Mike 21 HD Model two-dimensional flow modelling was done. The MIKE FLOOD model had been set up for both the case and the model results had been studied. Flood estimation was performed by six different methods. The contour planning results into development of land to safe grade elevation of all the grid points, while the general topography of the plant site is retained. This is helping in design for runoff generated from local site rainfall.

Mr. Sina Alaghmand presented a paper on comparison of two hydraulic models in regards to their capabilities of river flood risk analysis. A softer developed by Danish Hydraulic Institute (DHI) as MKE11 and by US Army Corps of Engineers as HEC-RAS4.0 is capable of performing river flood risk analysis. Comparison was made on the four aspects those are available outcomes, credibility, the availability and usability of the models. In this research Sungai Kayu Ara River basin was studied as case study which is located in Kuala Lumpur, Malaysia. Later observed water levels were compared against the results of the models. This research concludes that for river flood risk mapping HEC-RAS has more capabilities in comparison with MIKE11.

Mr. Smemoe in his paper on "Developing a Probabilistic Flood Plain Boundary Using HEC-RAS-1 and HEC-RAS", has discussed about probabilistic flood plain boundary development by using HEC-RAS and HEC-RAS-1.

In this paper an approach is developed for flood plain boundary to incorporate uncertainty in the modeling parameters during model development. Some general conclusions were made by the author for any project, on the bases of basic engineering principles similar solutions can be obtained while developing Flood Insurance Rate Map (FIRM). A develop a better modeling approach to get a flood plain boundary will requires integrated approach of uncertainty as the modeling parameters during model development. Delineation tools as a Computer operated flood plain is used to determine inundation depths and flood plain boundaries as the solutions of the series model. Finally a solution is generated in the form of probabilistic flood plain map. The contour on probabilistic flood plain shows percent probability of flooded location.

\section{CASE STUDY}

In the present study a Hypothetical case study of a construction site situated at the bank of river Mutha at seven $\mathrm{Km}$ downstream side of Khadakwasla Dam Project is consider.

For the study of such a site we had consider a reach of 10 $\mathrm{Km}$ of river Mutha from the downstream side of the Khadakwasla Dam. The Mahatre Bridge is selected as the gauging bridge site for the validation of the model. Tabel1 describes the data required. The data is collected from the irrigation offices, data user group and topographic sheets. The observed data for the application of the unit hydrographs approach were not available. Hence, in this study the synthetic unit hydrograph was derived using the estimation of flood.

Report for the Krishna and Pennar Subzone-3(h) is used as the base of the design of the discharge calculation for the $\mathrm{R}_{25}, \mathrm{R}_{50}, \mathrm{R}_{100}$.

Table1:- Description of data required and purpose

\begin{tabular}{|c|c|c|}
\hline $\begin{array}{l}\text { Sr. } \\
\text { No. }\end{array}$ & Data Required & Purpose \\
\hline 1. & $\begin{array}{l}\text { Cross section details of } \\
\text { the river. }\end{array}$ & $\begin{array}{l}\text { Construction of } \\
\text { Table Model }\end{array}$ \\
\hline 2. & $\begin{array}{l}\text { Catchment area of the } \\
\text { Kahadakwasla Project }\end{array}$ & \multirow{2}{*}{$\begin{array}{l}\text { Rain fall Analysis } \\
\text { And } \\
\text { Return flood }\end{array}$} \\
\hline 3. & Flood reports. & \\
\hline 4. & River Gauging Data & \multirow[t]{2}{*}{$\begin{array}{l}\text { Discharge data of the } \\
\text { Khadakwasla dam }\end{array}$} \\
\hline 5. & $\begin{array}{l}\text { Discharge data of the } \\
\text { Khadakwasla dam }\end{array}$ & \\
\hline
\end{tabular}




\section{METHODOLOGIES}

A. Analytical: - Design flood estimation is done by using various flood formulas. To design the flood the best analytical method is SUG method if scanty data is available.

A. Estimation of Extreme Rainfalls of Various Return Period: - To design flood estimation Probable Maximum Flood (PMF) using the synthetic unit hydrograph approach, the floods of various return periods using the Gumbel's based frequency analysis is found out. Gumbel (1941) introduced extreme value distribution and that is called as Gumbel distribution. It is most popular and adopted probability function for doing extreme values modelling of a random variable in hydrologic and metrological studies for the prediction of maximum wind speed, maximum rainfalls, etc. SUG method is based on the Unit Hydrograph method.

B. Design Strom: - To predict peak flood hydrograph unit hydrograph technique is used. Extreme rainfall situation were used to generate the design storm parameters. Detailed information about the rainfall and the resulting flood hydrograph were used to develop unit hydrograph for the selected catchment. But this information would be available for only few locations and will be very scanty. Majorities of the catchment areas, especially those which are located at remote locations always suffer with such conditions. Empirical equation of regional validity which relate the salient hydrograph characteristics to the basin characteristics are available and used to construct unit hydrograph for selected catchment area. The unit hydrograph derived using these relationships are called as synthetic unit hydrographs. SUG is a unit hydrograph of unit duration for a catchment developed. These unit hydrographs are based on the relation established between physiographic and unit hydrograph parameters of the representative gauged catchments in hydrometeorologically homogeneous region. It is possible to develop unit hydrograph if the site specific concurrent rainfall run-off data for every site is available for 5-8 years.

\section{Derivation of SUH (Synthetic Unit Hydrograph)}

Procedure to obtain parameters based on physiographic characteristics of the catchments and establishing relationship between physiographic parameters and unit hydrograph parameter to develop SUG is described in following paragraphs.

\section{Physiographic Parameters}

The physiographic parameters considered in the present study are:-

Catchment Area (A): - The gauging site is located on toposheet and the watershed boundary is marked. The area enclosed in this boundary up to the gauging site may be referred to as "A" as catchment area.

Length of Main Stream (L):- This implies the length of the longest main river/nala/stream from the farthest point on the watershed boundary of the selected catchment area to the gauging site.
Length of the main stream from the observation site to point near the centre of gravity of catchment $\left(L_{c}\right)$ :- For finding the centre of gravity of the catchment. Usually the boundary of the catchment is cut on a cardboard, which is then hung in three different direction in vertical planes and the plumb line are drawn from the point of hanging. The point of intersection gives the centre of gravity of selected catchment but the nearest point to the centre of gravity is consider to find the length of the main river from the centre of gravity to the point of study $\left(\mathrm{L}_{\mathrm{c}}\right)$.

Equivalent Stream slope (S):- One of the physiographic parameter is slope. The slope may be equivalent or statistical. In the present study equivalent stream or the slope has been replaced with statistical slope. Equivalent slope can be computed by analytical method .In this method L- section is broadly divided into 3 or 4 segments representing the broad ranges of the slopes of the segments and the following formula is used to calculate the equivalent slope (S):-

$\mathrm{S}=\left[\sum \mathrm{L}_{\mathrm{i}}\left(\mathrm{D}_{\mathrm{i}-1}+\mathrm{D}_{\mathrm{i}}\right)\right] /(\mathrm{L})^{2}$

Where,

$$
\begin{array}{ll}
\mathrm{L}_{\mathrm{i}} & =\quad \begin{array}{l}
\text { Length of the } \mathrm{i}^{\text {th }} \text { segment in } \mathrm{km} \\
\mathrm{D}_{\mathrm{i}-1}, \mathrm{D}_{\mathrm{i}}=
\end{array} \\
& \begin{array}{l}
\text { Elevation of river bed at } \mathrm{i}^{\text {th }} \text {, intersection } \\
\text { point of counter reckoned from the bed } \\
\text { elevation at points of interest considered } \\
\text { as datum and } \mathrm{D}_{\mathrm{i}-1} \text { and } \mathrm{D}_{\mathrm{i}} \text { were the highest } \\
\text { of the successive bed location at counter } \\
\text { and intersections. }
\end{array}
\end{array}
$$

$\mathrm{L}=$ Length of the longest steam in $\mathrm{km}$

A simplified approach for calculating the $\mathrm{Q}_{25}, \mathrm{Q}_{50}, \mathrm{Q}_{100}$ one of the method is Regression analysis. In these equations dependent variables are related to their respective physiographic parameters, A, L, $\mathrm{L}_{\mathrm{C}}$ and 24 hour point rainfall values. Following equation are used for calculation of 25 year, 50 year and 100 year flood discharge for each gauged catchment. [12]

$\mathrm{Q}_{25}=0.4285(\mathrm{~A})^{0.733}(\mathrm{~L})^{-0.264}\left(\mathrm{~L}_{\mathrm{C}}\right)^{0.264}\left(\mathrm{R}_{25}\right)^{1.426}$
$\mathrm{Q}_{50}=1.69432(\mathrm{~A})^{0.753}(\mathrm{~L})^{-0.338}\left(\mathrm{~L}_{\mathrm{C}}\right)^{0.304}\left(\mathrm{R}_{50}\right)^{0.934}$
$\mathrm{Q}_{100}=8.33488(\mathrm{~A})^{0.793}(\mathrm{~L})^{-0.422}\left(\mathrm{~L}_{\mathrm{C}}\right)^{0.313}\left(\mathrm{R}_{100}\right)^{0.416}$

Where $\mathrm{Q}_{25}, \mathrm{Q}_{50}, \mathrm{Q}_{100}$ are 25 year, 50 year and 100 year flood in cumec respectively.

$\mathrm{A}$ is the catchment area up to point of study in Sq.km.

$\mathrm{L}$ is the length of the longest main stream along the river course in $\mathrm{km}$

$\mathrm{L}_{\mathrm{C}}$ is the length of the longest main river/steam /nala from a point opposite to the centroid of the catchment area to the gauging site along the main stream in $\mathrm{km}$.

$\mathrm{R}_{25}, \mathrm{R}_{50}, \mathrm{R}_{100}$ are 24 hour point rainfall values in $\mathrm{cm}$ for the return flood of 25 year, 50 year and 100 year return period respectively. 
Compression between the result obtain is also studied for the suitability of the result obtain for small catchment area which is shown in the table 2 .

B. Soft Computational: - Soft computational modelling is done by using HEC-RAS. The program computes is based on Standard step method. By solving the one-dimensional energy equation water surface profiles from one cross section is produced and similarly the next profile is also produced [3].

This programme use momentum, continuity, and energy equations which describe the relationships among various flow variables, such as the discharge, flow depth, and flow velocity. By solving these equations, it is possible to determine the flow conditions throughout a specified channel length. These analyses yield the change in flow depth in a given distance or compute the distance in which a specified change in flow depth will occur. The channel cross section, bottom slope, the rate of discharge and Manning's n are usually known for these computations of steady state flow [3].

By differentiating the energy equation for a channel section between two river sections, the governing equation for gradually varied flow can be expressed as,

$$
\frac{d x}{d y}=\left(\mathrm{S}_{\mathrm{o}}-\mathrm{S}_{\mathrm{f}}\right) /\left[1-\left(\mathrm{aBQ}^{2}\right)\left(\mathrm{gA}^{3}\right)\right]
$$

Where, $\mathrm{S}_{\mathrm{f}}$ is the slope of the energy-grade line, $\mathrm{S}_{\mathrm{o}}$ is the slope of the channel bottom, as the velocity head coefficient, $\mathrm{B}$ is the bottom width of the channel, $\mathrm{Q}$ is the discharge and $\mathrm{A}$ is the cross sectional area of the channel.

After calculating the value for $\mathrm{Q}_{25}, \mathrm{Q}_{50}, \mathrm{Q}_{100}$ a table model is prepared with the help of HEC-RAS for Hydrological analysis of the flood discharge. This modelling is done to study the surface profile of the river at the time of the flood.

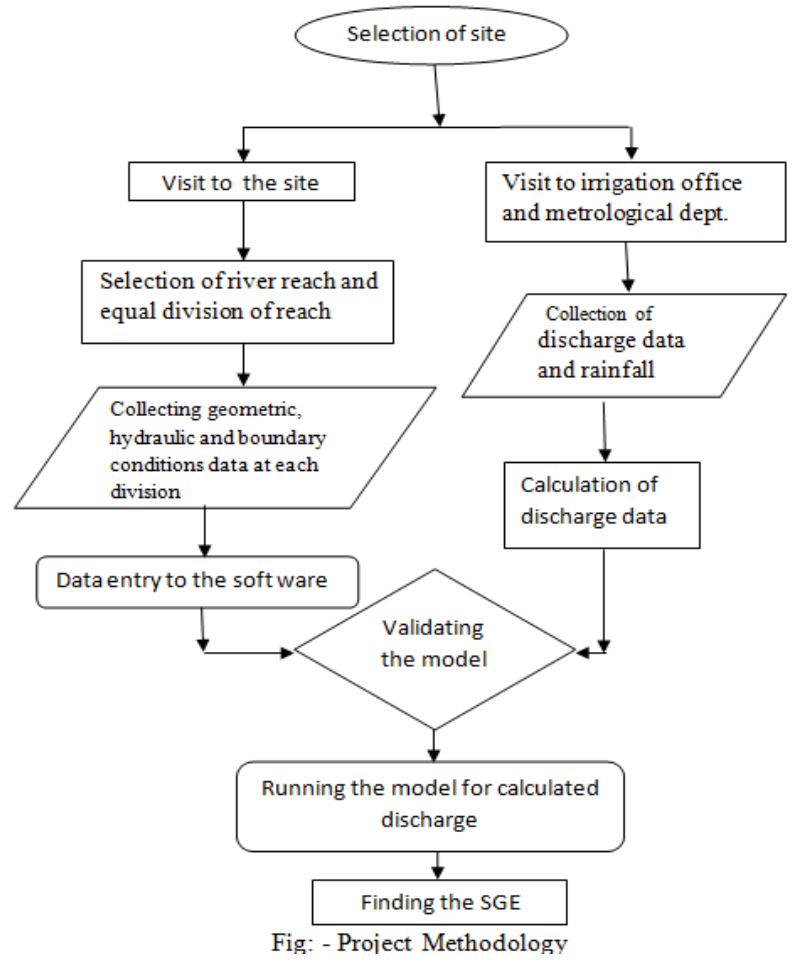

\section{RESULT}

By using this data the model is run for different returns period floods and the surface profile of these discharge at the selected site are taken as the level of water at the time of flood. Table 2 shows the various discharge obtained by using SUH Method and Regression analysis. The variation of the result obtained with regression with respect to SUG is not acceptable. Hence the discharge values obtain by SUH method is used as an input to for the table model.

Table 2. Compression between SUG and regression result values

\begin{tabular}{|c|l|l|c|r|r|}
\hline Sr. No & Name of catchment area & Return Periods & By SUG & By Regression & Variation With Respect To SUG \% \\
\hline 1 & Khadakwasla & R25 & 811.42 & 874.21 & -7.738285968 \\
\hline 2 & Khadakwasla & R50 & 923.7 & 1063.05 & -15.0860669 \\
\hline 3 & Khadakwasla & R100 & 988.24 & 1357.727 & -37.38838744 \\
\hline 4 & Temghar & R25 & 710.8133 & 792.6 & -11.5060734 \\
\hline 5 & Temghar & R50 & 780.0317 & 577.3242 & 25.98708488 \\
\hline 6 & Temghar & R100 & 840.1414 & 422.4739 & 49.71395291 \\
\hline 7 & Varasgaon & R25 & 1025.7 & 1161.9 & -13.27873647 \\
\hline 8 & Varasgaon & R50 & 1104.18 & 1020.144 & 7.610715644 \\
\hline 9 & Varasgaon & R100 & 1182.08 & 927.8449 & 21.50743604 \\
\hline 10 & Pansheet & R25 & 893.4732 & 1043.984 & -16.84558641 \\
\hline 11 & Pansheet & R50 & 962.8323 & 922.0161 & 4.239180593 \\
\hline 12 & Pansheet & R100 & 1031.614 & 982.4364 & 4.767054344 \\
\hline
\end{tabular}


The model is validated from the data provided for the Mahtre Bridge gauging site. So elevation above that surface is the safe grade elevation for the construction of the building.

According to the functional and the economical importance the safe grade elevation of the structures are selected.

\section{CONCLUSION}

1. After validation of the model for the maximum discharge on $30^{\text {th }}$ July 2006 and $11^{\text {th }}$ August 2006 for Mahtere Bridge Site model was run for the return period flood.

2. The level for the purposed site for $R_{25}$ was found to be $553.71 \mathrm{~m}$, for $R_{50}$ was found to be $554.03 \mathrm{~m}$, for $R_{100}$ was found as $554.29 \mathrm{~m}$.

3. After studying this project following points can be concluded

a. The HEC-RAS has better performance than the MIKE11.

b. There is very less increase of flood discharge and level of $R_{25}, R_{50}$ and $R_{100}$.

c. SUH method for the flood design holds more accuracy than regression equation for small catchment areas.

\section{ACKNOWLEDGMENT}

I am thankful to Hydrological Data user group, Centeral Water Commission, Irrigation Department, Government of Maharashtra for providing me Case study data. I would like to thank Deputy Eng. Mrs. Deepgauri A. Joshi, Sectional Eng. Mr. Khate for their kind Support and all who have directly or indirectly helped me during the course of this work, and whose names have been missed here to record.

\section{REFERENCES}

[1] Central Water Commission. CWC (1984) Flood estimation report for Upper Indo-Ganga plains (subzone-1e)

[2] "Estimation of Design Basis Flood and Safe Grade Elevation for Nuclear Power Project at Gorakhpur, Haryana" A report by CWPRS

[3] USACE, Hydrologic Engineering Centre, River Analysis System HEC-RAS, Hydraulic Reference Manual version 3.0, January 2001. www.usace.army.mil

[4] National institute of hydrology (1999) "Computation of water surface profile using HEC-RAS" CS (AR)30/98-99

[5] Http://www.mapsofindia.com/top-ten/geography/indiaflood.html

[6] Http://pune.nic.in/punecollectorate/punecity/climate.as px

[7] Kumar, R. and Chatterjee, C. Regional flood frequency analysis using L-moments for North Brahmaputra Region of India. J. Hydrologic Engineering, ASCE, 10(1), 1-7 (2005).
[8] Kumar, R., Chatterjee, C. and Kumar, S. 2003 Regional flood formulas using L-moments for small watersheds of Sone Subzone of India". Journal of Applied Engineering in Agriculture, American Society of Agricultural Engineers. Vol. 19, No. 1, pp.47-53.

[9] Kumar, R., Singh, R.D., and Seth, S.M. (1999). "Regional flood formulas for seven subzones of zone 3 of India." J. of Hydrologic Engrg. ASCE, 4(3), 240244.

[10] Technical requirements for flood control and beneficial purpose regulation management of Banqiao reservoir reconstruction project $[\mathrm{R}]$. Tianjing: Tianjing survey and design institute, 1993.

[11] National institute of hydrology (1999) "Computation of water surface profile using HEC-RAS” CS (AR)-30/9899

[12] Central water commission flood estimation report for the Krishna and Pennar Subzone-3h

[13] Developing a Probabilistic Flood Plain Boundary Using HEC-RAS-1 And HEC-RAS Smemoe, C.Nelson $J$ and Zundel A. (2003) World Water \& Environmental Resources Congress 2003

[14] One and Two Dimensional Model Studies for Prediction of Changes in Flow Conditions in Panvel Creek due to Development of Proposed International Airport at Navi Mumbai, Maharashtra Review of CWPRS Draft Report

[15] Identification and classification of flood prone areas using AHP, GIS and GPS, Bhagat Madhuri, Ghare Aniruddha and Ralegaonkar Rahul, . 